\title{
UNUSUAL PRESENTATION OF LYMPHOMA
}

Varunjikar M.D ${ }^{1}$, Shital Varunjikar², Bejoy E Jayan³ ${ }^{3}$ A.M. Varunjikar ${ }^{4}$, Joshi C.R ${ }^{5}$

\section{HOW TO CITE THIS ARTICLE:}

Varunjikar M.D, ShitalVarunjikar, Bejoy E Jayan, A.M. Varunjikar, Joshi C.R. "Unusual Presentation Of Lymphoma”. Journal Of Evolution Of Medical And Dental Sciences 2013; Vol2, Issue 50, December 16; Page: 9645-9650.

ABSTRACT: Uniform swelling of thigh is a rare entity. Such swelling may be due to hematoma / abscess in muscular and subcutaneous planes. It may besecondary to some tumor inthe thigh,may be arising from bone or soft tissue. In this study, the case of a 67-year-old male with a swelling in left thigh and dull aching pain is presented. CT imaging revealed fusiform swelling diagnosed as organizing hematoma. USG supported the diagnosis. Thetentative diagnosis was of a organized hematoma of left thigh was made, swelling was explored, and sample was sent for biopsy.Histological examination of the swelling revealed the diagnosis of Non hodgkins lymphoma.

KEYWORDS: thigh swelling, organized hematoma, biopsy, Non-Hodgkin's lymphoma.

INTRODUCTION: Non-Hodgkin lymphoma (NHL) arising from the soft tissue of the extremities is rare $^{1}$, and its clinical manifestation and defects observed on magnetic resonance imaging and computed tomography are characteristic features. Itis sensitive to chemo-therapy and radiotherapy. The histological diagnosis should be identified as far as possible before the tumor is widely excised.The clinical features of NHL mimic those of other soft tissue tumors, particularly sarcoma or even any fluid collection, such as, blood or pus; however, they should be differentiated, as the treatment and prognosis are completely different.

CASE REPORT: A 67-year-old male presented to the Department of Orthopaedics with a 11-month history of a swelling ofleft thigh following a trivial traumawith difficulty in walking. The patient was apparently well prior to the illness andpast medical history was uneventful. Physical examination revealed a mal-nourished man with no abnormal findings on systemic examination.Inguinal lymph nodes were palpable but were non-tender and mobile.The patient was found to have a hugefusiform swelling circumferentially around the middle third of the thigh. Swelling was not highly tender, skin was stretched with dilated veins, temperature was normal. There was no distal neurovascular deficit. Knee joint had mild effusion and signs of early degenerative changes. Lab reports revealed anaemia (Hb -5.7 gm/dl). Other reports such as TLC, ESR, Alkaline Phosphatase, RFT, LFT, TLC, PTINR, HIV, HbsAg.Xray chest were normal.

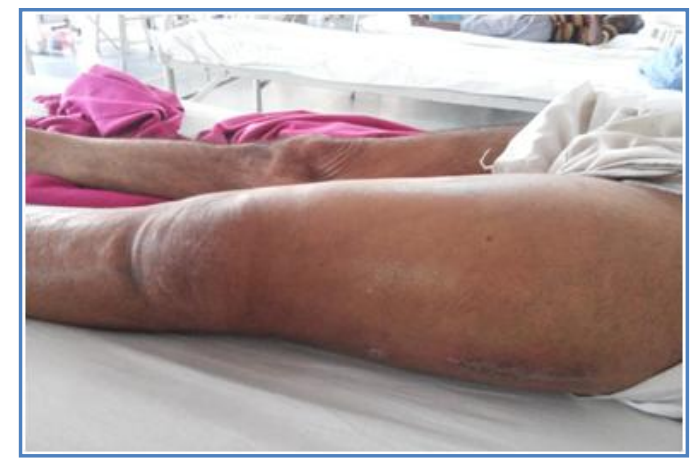

LEFT THIGH OF PATIENT 


\section{CASE REPORT}

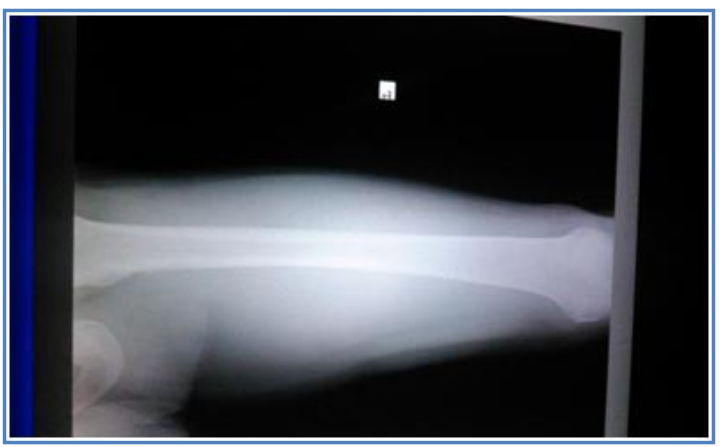

Xray of the left thigh AP showing fusiform swelling in middle third of thigh without affection of bone

CTimaging revealed an approximate fusiform shaped massin submuscular plane not infiltrating the bone. No evidence ofcompressionof blood vesselswas noted. Tentative diagnosis of organizing hematoma was made based on CT and sonography reports.

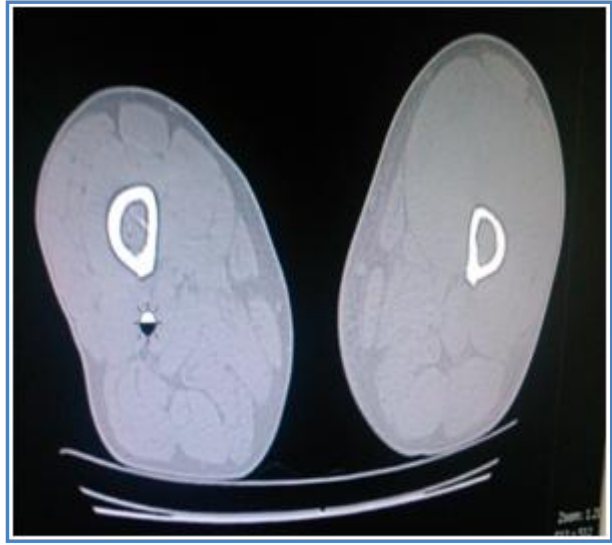

CT of both thighs

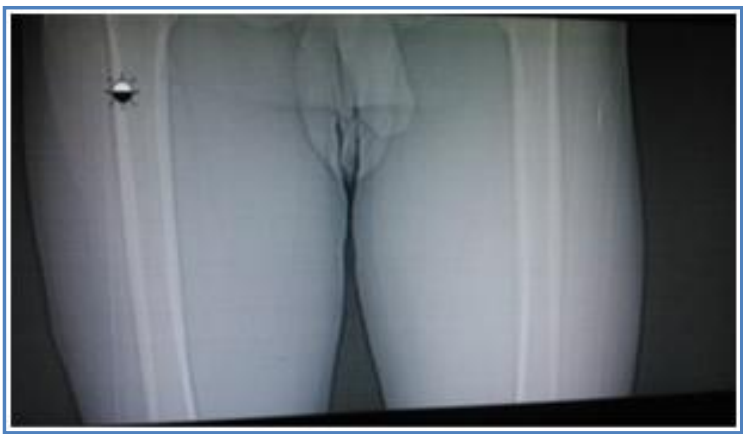

CT scan of both thighs

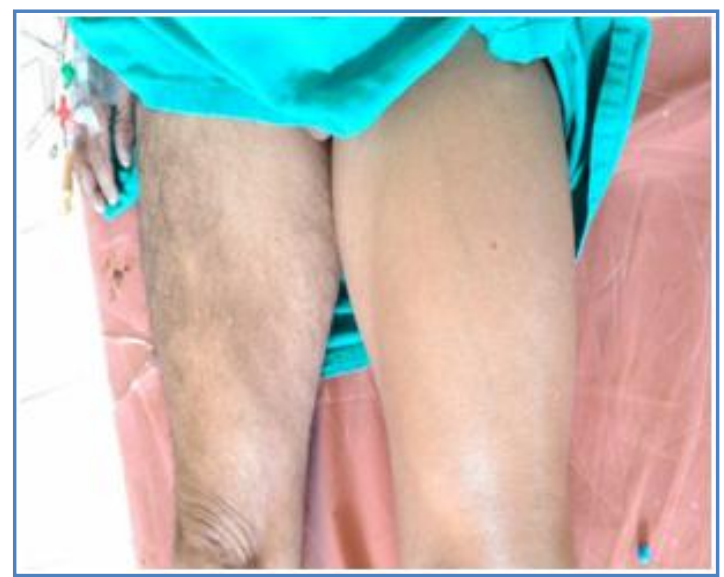

COMPARATIVE PICTURE OF BOTH LIMBS 
Due to the huge size of the mass,it was difficult to separate and excise in toto. So, wide biopsy ofsoft connective tissue of thethigh was performed by lateral approach under spinal anaesthesia.

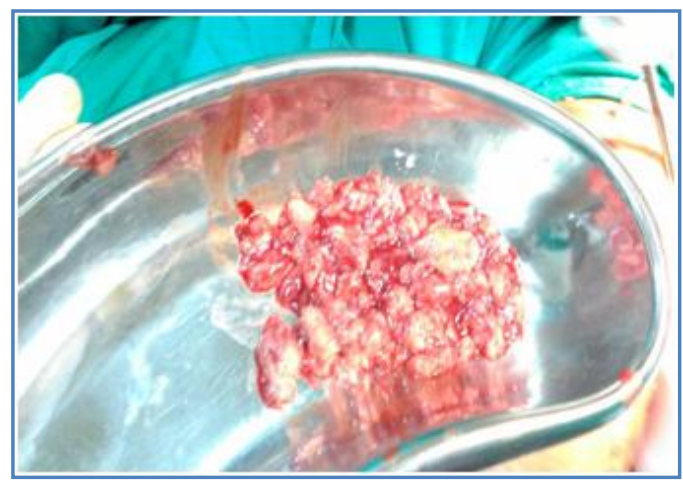

BIOPSY MATERIAL

Histopathology revealednumerous lymphocytes, polymorphs and few plasma cells separated by fibro-collagenous bands with similar cell infiltration. Additional section showedhypercellular mass composed of round to oval cells, i.e. large and small lymphocytes diffusely arranged with scanty stroma, with few plasma cells and neutrophils. Nucleoli present in few cells with epitheloid appearance of cells, suggestive of non-hodgkins lymphoma of thigh.

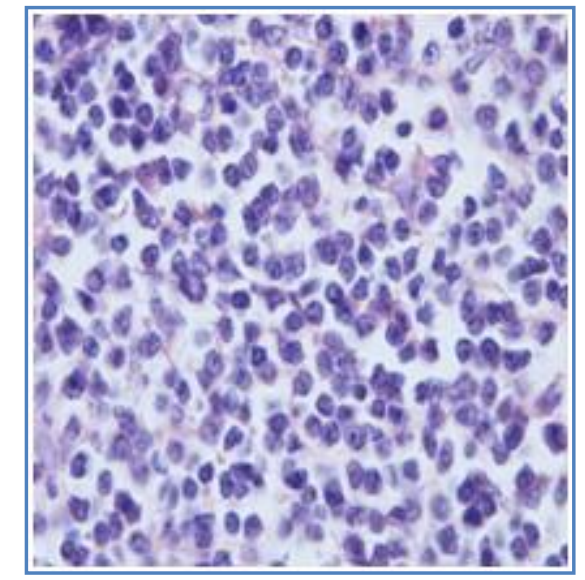

HPE of non-hodgkins lymphoma.

Following surgery, the patient was referred to higher centre for further management. Prognosis and follow up of the patient is awaited.

DISCUSSION: Malignant lymphoma may present in any region of the body. The condition is referred to as primary extranodal NHL when the extranodal site is the only site involved or when the bulk of the disease is confined to the extranodal site $^{2}$. The most common extranodal sites include the gastrointestinal tract, Waldeyer's ring, head and neck, testes, ovary, central nervous system, thyroid, breast, bone and skin, in order of decreasing frequency ${ }^{3-13}$. Primary NHL localized in the soft tissue of the extremities is uncommon. Certain reports suggest that true primary NHL in the soft tissue of the extremities represents approximately $0.11 \%$ of all malignant lymphomas ${ }^{1}$. Meanwhile, diseases 
such as lymphoma or pseudolymphoma of the skin, histocytic variants of malignant fibrohistiocytoma or manifestations of systemic lymphoma should be ruled out at the time of diagnosis. The symptoms are nonspecific and may mimic other entities, such as rhabdomyosarcoma, Ewing's sarcoma, fibrosarcoma, liposarcoma, synoviosarcoma and metastatic carcinoma and rarely hematoma. As a consequence of its low incidence, a standard treatment for primary soft tissue nonHodgkin lymphoma has not been clearly defined. Considering that the therapy for malignant lymphoma is very different from that for other soft tissue malignancies, accurate diagnosis should be established prior to definitive treatment.

Several studies have found MR imaging to be superior in the evaluation of soft tissue tumors compared with $\mathrm{CT}^{14-16}$. There are a few reports describing the MR imaging findings of lymphoma in the soft tissue of the extremities ${ }^{1,17}$ : a large soft tissue mass with equal to slightly low signal intensity on T1-weighted images and markedly high signal intensity on conventional T2-weighted images, without osseous involvement, but with infiltration of skeletal muscle and surrounding soft tissues was observed. Therefore, Lee et al ${ }^{17}$ recommend that, at MR imaging, if a large soft-tissue mass with normal adjacent bone marrow or a mass more extensive than the adjacent bone marrow abnormalities that affects a long segment of an extremity with diffuse muscle involvement is observed, and there is the presence of subcutaneous stranding or extension, the differential diagnosis should include and favor primary soft tissue lymphoma in the absence of a history of trauma or infection. CT is commonly the imaging method of choice for the detection and staging of lymphoma ${ }^{18}$. CT enables accurate measurement of both the size and extent of the tumor, and provides information to determine appropriate therapy and response to treatment.

The histological subtype, location and the approach to therapy appear to have some correlation with the clinical outcome of soft tissue lymphoma of the extremities ${ }^{1}$. In conclusion, surgical excision is the main treatment for most primary soft tissue tumors. Nevertheless, primary extremity lymphomas are rare tumors with potentially high malignancy and metastatic capacity, exhibiting clinical and histological difficulty for a correct diagnosis. The presence of an intense soft tissue mass on MR imaging, particularly in a middle- or older-aged patient, is highly suggestive of lymphoma. Considering the sensitivity to chemotherapy and radiotherapy, amputation of the extremity is not optimal for lymphomas. FNAC is seldom adequate to establish diagnosis. Biopsy of the mass and histopathological examination are essential to distinguish lymphoma from other malignant round-cell tumors. Early recognition and correct diagnosis will allow the proper treatment protocol to be initiated.

In brief, even though rare,one should keep in mind differential diagnosis of lymphoma in uniform, slow growing swelling of thigh presenting with history of few months without causing acute disability.

\section{REFERENCES:}

1. Travis WD, Banks PM, Reiman HM. Primary extranodal soft tissue lymphoma of the extremities. Am J SurgPathol. 1987;11:359-366. [PubMed]

2. Komaki R, Cox J, Hansen R, Gunn W, Greenberg M. Malignant lymphoma of the uterus and cervix. Cancer. 1984;54:1699-1704. [PubMed]

3. Hariprasad R, Kumar L, Bhatla DM, Kukreja M, Papaiah S. Primary uterine lymphoma: Report of 2 cases and review of literature. Am J Obstet Gynecol. 2006;195:308-313. [PubMed] 


\section{CASE REPORT}

4. Kolve ME, Fischbach W, Wilhelm M. Primary gastric non-Hodgkin's lymphoma: requirements for diagnosis and staging. Recent Results Cancer Res. 2000;156:63-68. [PubMed]

5. Laskar S, Mohindra P, Gupta S, Shet T, Muckaden MA. Non-Hodgkin lymphoma of the Waldeyer's ring: clinicopathologic and therapeutic issues. Leuk Lymphoma. 2008;49:22632271. [PubMed]

6. King AD, Lei KI, Ahuja AT. MRI of neck nodes in non-Hodgkin's lymphoma of the head and neck. Br J Radiol. 2004;77:111-115. [PubMed]

7. Sasai K, Yamabe H, Tsutsui K, Dodo Y, Ishigaki T, Shibamoto Y, Hiraoka M. Primary testicular non-Hodgkin's lymphoma: a clinical study and review of the literature. Am J ClinOncol. 1997;20:59-62. [PubMed]

8. Ray S, Mallick MG, Pal PB, Choudhury MK, Bandopadhyay A, Guha D. Extranodal non-Hodgkin's lymphoma presenting as an ovarian mass. Indian J PatholMicrobiol. 2008;51:528-530. [PubMed]

9. Camilleri-Broët S, Martin A, Moreau A, Angonin R, Hénin D, Gontier MF, Rousselet MC, CauletMaugendre $S$, Cuillière $P$, Lefrancq T, et al. Primary central nervous system lymphomas in 72 immunocompetent patients: pathologic findings and clinical correlations. Am J ClinPathol. 1998;110:607-612. [PubMed]

10. Colović M, Matić S, Kryeziu E, Tomin D, Colović N, Atkinson HD. Outcomes of primary thyroid non-Hodgkin's lymphoma: a series of nine consecutive cases. Med Oncol. 2007;24:203-208. [PubMed]

11. Hinoshita E, Tashiro H, Takahashi II, Onohara T, Nishizaki T, Matsusaka T, Wakasugi K, Ishikawa T, Kume K, Yamamoto I, Hirota Y. Primary non-Hodgkin's lymphoma of the breast: a report of two cases. Breast Cancer. 1998;5:309-312. [PubMed]

12. Pant V, Jambhekar NA, Madur B, Shet TM, Agarwal M, PuriA, Gujral S, Banavali M, Arora B. Anaplastic large cell lymphoma (ALCL) presenting as primary bone and soft tissue sarcoma - a study of 12 cases. Indian J PatholMicrobiol. 2007;50:303-307. [PubMed]

13. Theander E, Henriksson G, Ljungberg O, Mandl T, Manthorpe R, Jacobsson LT. Lymphoma and other malignancies in primary Sjögren's syndrome: a cohort study on cancer incidence and lymphoma predictors. Ann Rheum Dis. 2006;65:796-803. [PMC free article] [PubMed]

14. Lai YC, Chiou HJ, Wu HT, Chou YH, Wang HK, Chen PC. Ultrasonographic and MR findings of alveolar soft part sarcoma. J Chin Med Assoc. 2009;72:336-339. [PubMed]

15. Kransdorf MJ, Jelinek JS, Moser RP., JrImaging of soft tissue tumors. RadiolClin North Am. 1993;31:359-372. [PubMed]

16. Verstraete KL, Lang P. Bone and soft tissue tumors: the role of contrast agents for MR imaging. Eur J Radiol. 2000;34:229-246. [PubMed]

17. Lee VS, Martinez S, Coleman RE. Primary muscle lymphoma: clinical and imaging findings. Radiology. 1997;203:237-244. [PubMed]

18. Fishman EK, Kuhlman JE, Jones RJ. CT of lymphoma: spectrum of disease. Radiographics. 1991;11:647-669. [PubMed]

19. Dey P, Mallik MK, Gupta SK, Vasishta RK. Role of fine needle aspiration cytology in the diagnosis of soft tissue tumours and tumour-like lesions. Cytopathology. 2004;15:32-37. [PubMed] 
20. Amin MS, Luqman M, Jamal S, Mamoon N, Anwar M. Fine needle aspiration biopsy of soft tissue tumours. J Coll Physicians Surg Pak. 2003;13:625-628. [PubMed]

21. Bennert KW, Abdul-Karim FW. Fine needle aspiration cytology vs. needle core biopsy of soft tissue tumors. A comparison. ActaCytol. 1994;38:381-384. [PubMed]

\section{AUTHORS:}

1. Varunjikar M.D.

2. Shital Varunjikar

3. Bejoy E. Jayan

4. A.M. Varunjikar

5. Joshi C.R.

\section{PARTICULARS OF CONTRIBUTORS:}

1. Associate Professor, Department of Orthopaedics, VikhePatil Medical College, Ahmednagar.

2. Consulting Anaesthesiologist and Intensivist, Department of Orthopaedics, VikhePatil Medical College, Ahmednagar.

3. Senior Resident, Department of Orthopaedics, VikhePatil Medical College, Ahmednagar.
4. Consulting Anaesthesiologist and Intensivist, Department of Orthopaedics, VikhePatil Medical College, Ahmednagar.

5. Consulting Radiologist, Department of Orthopaedics, VikhePatil Medical College, Ahmednagar.

\section{NAME ADRRESS EMAIL ID OF THE CORRESPONDING AUTHOR:}

Dr. Varunjikar M.D.,

Tathastu, 54, Deshmukh Colony, Opposite Civil Hospital, Camp Satara - 415001.

Email-varunhsp@yahoo.co.in

Date of Submission: 25/11/2013.

Date of Peer Review: 26/11/2013.

Date of Acceptance: 03/12/2013.

Date of Publishing: 10/12/2013 